\title{
Sustainability of Self-Efficacy among Nascent Disable Entrepreneurs: A Case Study on Disable's Home
}

\author{
Farhana Firoz ${ }^{1}$, Muntasir Alam ${ }^{2}$
}

${ }^{1}$ Senior Lecturer, Department of Management, North South University, Dhaka, BANGLADESH

${ }^{2}$ Senior Lecturer, Department of Accounting \& Finance, North South University, Dhaka, BANGLADESH

\begin{abstract}
The study has focused on practicality of self-efficacy theory, and how it helps to build confidence among the disables in building their career choice as entrepreneurs. For this we chose a case study approach on Disable's home, which is a non-profit organization to provide support for disables. The study was conducted in two phases. First phase, from disable people's perspective who were trainees in the Disable's home. And second, from the Disable's home's perspective. Findings of the first phase suggest, in order to sustain self-efficacy with regard to career choice as entrepreneurs, not only institutional support is enough but other additional supports like social, financial, family supports are important. In the second phase, it was observed that institution needs to be resourceful in order to provide proper support to the disables and embed self-efficacy among them.
\end{abstract}

Keywords: disable people, self-efficacy

JEL Classification Code: M31

\section{INTRODUCTION}

Case studies as tools for generating and testing theory have provided the strategic management field with ground-breaking insights (e.g., Penrose, 1960; Pettigrew, 1973; Burgel-man, 1983). Therefore, keeping this in mind, in this case study, self-efficacy theory and its importance to be an entrepreneur among disabled people is analyzed. As a case study we selected Disable's home (it was being used a pseudonym for the organization for anonymity). This is because Disable's homes exist around the world. In Bangladesh, Disable's home is situated in the capital city, Dhaka. It is a proud member of a leading NGO whose branches are spread all over the world in fifty two countries \& it is indeed a true home for the disabled, men, women and children.

In general very few studies have been done on disable people and them being self-employed, i.e -being entrepreneur. And none of the studies are found which explain their situation in terms of self-efficacy theory. This case study provides an analysis of the self-efficacy theory in career choice as entrepreneurs of disable people. In doing so, the study aims to further build on the application of the term 'self-efficacy' and how it leads to ultimate career choice to be an entrepreneur by emphasizing the situation of selected case of disable people. It is suggested that a person's intention and ability to engage in certain activities is affected by self-efficacy, that is, the extent to which one has confidence in his or her own capabilities (e.g. Bandura , 1978 ; Boyd and Vozikis , 1994) and so it is a very important concept to understand. There are several literature on self-efficacy and its significance in career choices(e.g. Bandura,1977; Bandura et.al., 2001; Kickul, et al. 2004; Scherer,et.al.1989; Hollenbeck and Hall, 2004; Lent and Hackett,1987; Nevill $\&$ Schleckler,1988) and there is a developing literature on the position of disable people in the labor market and about their quality of life issues (e.g. Hosain et al., 2002; Mont,2004 ; Kidd et al,2000), but unfortunately, no literature is found on disabled people's career choice in terms of their self-efficacy. As a consequence, there is a limited understanding of how best to support disable people's role in entrepreneurship in a developing nation, like Bangladesh. Hence the rationale of the study is the applicability of self-efficacy theory in understanding and informing this process of disable people's progress in the society. The significance of the study is to address the gap in the literature that leads to lack of enough knowledge about how disable entrepreneurs understand their careers, and how they respond to the opportunities and barriers that they face while they pursue their careers.

The paper is arranged in three stages. First, condition of disable people and self -efficacy theory are reviewed from the existing literature. Second, self-efficacy factor of disable people is analyzed in two phases: first phase is studied from disable people's self-efficacy perspective. And, phase two from institutional perspective regarding their strength \& weaknesses to support disables. Followed by conclusion.

\section{LITERATURE REVIEW}

What is disability?

The World Health Organization has defined health as "a complete physical, mental and social well-being and not merely the absence of disease or infirmity." The concept 
has more recently been extended to include health related quality of life (WHO 1980, 1993). Disabilities and handicap, impairment is concerned with physical aspects of health according to the international classification of impairments (Hosain, 2002). Whereas impaired organ can result in disability which causes functional capacity (WHO 1980). Therefore, disability can affect physical health, social life, life in realms of family, psychological state and level of independence (Barbotte et al.,2001). And if this is so then disability may affect people's career choice as well. Because people with disabilities have remain at the margins of society as one of impoverished groups (Imrie, 1997). Moreover, in a study done by (Kidd et al., 2000) found, the disabled are more likely to be absent from work due to sickness and length of absence is likely to be longer in their case. The able-bodied on average have higher educational qualifications than the disabled, but shorter labor market experience and slightly lower tenure with the current employer, reflecting the association of disability with age. The disabled are under-represented relative to the able bodied in the high paying managerial and professional occupations. So, this may imply that disability creates obstacles in the ladder of career development and may induce the people with disability to choose entrepreneurship as their career choice. In addition, to the disadvantage of being disable there is another factor, called 'self-efficacy' which also plays a role in career choice of people. Why there are small numbers of disable workforce in the market, especially in the area of entrepreneurship can be largely explained by self-efficacy theory.

\section{Background of Self- Efficacy}

Self-efficacy is central to intentions towards entrepreneurship and also it predicts opportunity recognition (Scherer, et. al., 1989). To understand entrepreneurial intentions, it is essential to understand the background of self-efficacy.

Social learning theory of Bandura (1977) gave rise to the term 'self-efficacy' and it referred mainly to a person's self-belief of his or her capability to take or perform a task. In his original work, Bandura (1977) defined self-efficacy expectations, as one's own belief about his/ her capabilities to perform an action or execute a behavior successfully. In realm of this, Bandura hypothesized efficacy expectations would help to determine initiation of a particular behavior, expended effort, how long the persuasion would stay when faced with obstacles and non- favorable experiences. Bandura described personal efficacy as a powerful side of the self rather than a passive characteristics that had the capability to interact not only with the complexities of real life environment but also with outcome expectations and accomplishments. Also, he said that people judge about their personal capabilities by self-efficacy that in turn again influences performances but was not reducible to objective skills but rather it determined what people could do with their skills.
Therefore, it would not be wrong to say that whether to engage in entrepreneurial behavior, self-efficacy could be a an important tool in explaining the powerful process of evaluation and choice that surrounds the development of entrepreneurial a person to role play in the development of desirability or intensions because whether a goal can be achievable was decided by self-efficacy (Bandura, 1977). Another way to improve self-efficacy was through the social persuasion. Receiving favorable feedback \& attainable encouragements about task performance may likely results in greater effort (Gist, 1987; Wood \& Bandura, 1989). Combining all these concepts together, when self-efficacy is assumed as a key preceding factor to new venture intentions, it is called as entrepreneurship self-efficacy (Boyd \& Vozikis, 1994; Chen et al. 1998; Krueger \& Brazeal, 1994).

Some factors can help in self-efficacy development. In a study done by Arenius \& Clereq (2005), they found a positive effect of one's educational level and the likelihood to perceive entrepreneurial opportunities. And similarly, it was found in the work of Arenius and Minniti (2005) that probability of being a nascent entrepreneur increased very steadily as individuals had higher education. So, from these findings it can be argued that individuals can gain self-efficacy or self-confidence to start up a new venture with education, that is, the anticipated success of new venture creation increases when one believes oneself to hold knowledge related to entrepreneurship, and therefore an individual would be more likely to intend business startup activity as a feasible career option. But this knowledge-based view on entrepreneurial activity does not only mean individual's existing knowledge but also individual's exposure to external knowledge. External knowledge implies the importance of one's access to knowledge held by others, and this had a sociological view, which saw human action and perceived individuals as actors who were shaped by societal factors (Burt, 1992; Putnam, 1993).Therefore, societal factors were very important to develop self-efficacy.

So from these discussions, it can be said that, self-efficacy is not biologically obtained but it is developed with not only through education but also other factors, like proper training, family support, institutional support, social position in careers and stereotyped role in the society. These factors have impact on people's self-efficacy and ultimately in their career choice (Herron and Sapienza, 1992 ; Gist,1987 ; Gist and Mitchell,1992 ; Bandura,1982; Boyd and Vozikis,1994; Krueger and Brazeal,1994).

The quality of social life of disable people in developing nation is much more under-privileged and marginalized (Hosain et al., 2002). In a developing country like Bangladesh, where life is difficult for many able-bodied people, disable are more likely to face much greater problems and social hardship in the absence of a disablefriendly environment (Hosain et al.,2002). These people are less likely to get educated, employed or rehabilated. 
In addition, since social segregation of disable people is extremely widespread (Brown, 1988), these people do not get special privileges from social welfare services (Hosain et al.,2002). As a consequence, most of the disable people face insensivity, cruelty and often pity from the society. The dominance of a medical model of disability has tend to 'blame the victim' which, as Imrie stated, people with disabilities as 'inferior', dependent and of no value (Imrie, 1997). These situations prohibits development of self-efficacy among disable persons and can be probable explanations of their less presence in labor force and lack of intention to have strong career . Therefore, keeping the information in mind from the literature, we tried to observe whether disable people choose career to be an entrepreneur by gaining selfconfidence with the help of an institutional support and whether the acquired confidence sustains. And so we reached to two propositions:

P I: Organizational support can build self-confidence which will lead to be an entrepreneur.

P II: Organization's strengths and weaknesses will play an important role in providing support for the disable people in building their self - efficacy

\section{Methodology}

The study is divided in two phases. In phase one, we examined PI and in phase two, we examined PII.

\section{Phase one sample}

Sample of ten people was collected randomly and by taking consent of the chosen sample from the group of 30 trainees who were taking training during the study period. We chose focus group as our method of analysis in phases one, to find the development of self-efficacy towards career choice as entrepreneurship of disable people through an institutional support. Unlike quantitative methods, focus group is qualitative and not intended to provide statistical inference or generalize findings. Here it provided a way to understand the nature of the perceptions of disable persons' believe towards their ability to be an entrepreneur who are taking training in Disable's home. The rationale for qualitative inquiry and research design was based on Creswell's definition of qualitative research that it is a process of understanding based on analysis of words, that it reports detailed views of informants, and that it is conducted in a natural setting. Focus group method was chosen for our data gathering because the information about having self-efficacy for entrepreneurship was likely more complex than a questionnaire could reveal and we thought that focus group would provide more honest and in-depth information.

According to Atkinson (2009), compared to individual interviews, focus groups allowed greater amounts of information to be gathered more efficiently and enabled the observation of interactions between participants, providing additional insight. This approach to selection relates to the concept of 'Applicability', in which subjects are selected because of their knowledge of the study area (Burrows \& Kendall, 1997). One of the distinct features of focus-group interviews is its group dynamics; hence the type and range of data generated through the social interaction of the group are often deeper and richer than those obtained from one-to-one interviews (see Thomas et al. 1995).

\section{Phase two sample}

In the Phase II, questions were asked to three individuals from the management of the Disable's home. Study of analysis was by individual interview in this segment. We chose individual interview method here because in depth view regarding the management \& operational activities could be obtained if we do one to one interview. This phase of the study assessed how institutional support may be effective to develop self-confidence among disables to have their own business, the richest data possible, particularly in the absence of preexisting studies.

\section{Procedures \& variables}

The study is divided into two phases. Phase one, was carried out to see how trainees' perception differed while taking training and at the end of the training towards their self-confidence of being an entrepreneur. To check this we proposed P1:

Organizational support can build self-confidence which will lead to be an entrepreneur. This proposition has been checked with two sets of questionnaires. Set A questions, which included the followings:

- What training(s) you are getting from Disable's home and for how long?

- What are the training incentives are you getting through Disable's homes?

- What are your career future plans after finishing the training at Disable's home?

The aim of these questions were to find what are the institutional support the disable people were getting and how they perceive it would be beneficial for their future career plans. Set A questions were asked to the focus group interview when the disable members were in the middle of their training.

Set B questions were asked to the same focus group when they were about to finish their training. Set B included the followings:

- Do you think that the training you received in Disable's home will be useful for your own business set-up?

- Do you have any external support to set up your own business after leaving Disable's homes?

- What are your career future plans after finishing the training at Disable's home?

These questions designed to compare whether there is any change in their self - confidence before and after they received their training. 
The second phase (Phase two) of the study was designed to find institutional view in building confidence among the disables and their own strengths and weaknesses. The second proposition was as follows:

Organization's strengths and weaknesses will play an important role in providing support for the disable people in building their self-enhancement.

And to find this, three questions were asked to three people in the management. The manager, one of the directors and an officer were selected and were interviewed with the following questions:

- What are the constraints Disable's home are facing?

- What support the institution is providing to the disable people?

- What could have been better than the current situation?

\section{Analysis and Interpretation}

Focus group interview and individual interview were audio taped, had note takers, and were moderated by one of the authors. To ensure proper rigor for analysis of qualitative data, transcripts were typed verbatim from the recordings. Code names were used for participants to maintain anonymity. In phase one, the first set (Set A) of questions were asked to assess the level of self efficacy obtained by the trainees through the training from Disable's home. It has been observed that a difference in opinion with respect to self efficacy exists when they were at the middle of the training period with that of when they were at the end of training period.

In the middle of the training period, when asked about their training type and for how long they will get training, the trainees informed us that they were mostly getting training on making handicraft goods for three months, twice a week. Next, we asked whether any kind of training incentives they get from Disable's home, we were informed by the focus group that they get a minimum amount of monetary incentive which ranges from 100 taka (approx. \$1.25) to 200 taka (approx.\$2.5) if they can show any productive work. Most positive answer came when we asked about their future plans. Approximately six to seven out of the ten disable trainees in the focus group were very hopeful and gave indication to set up their own small business or selfemployment once they finish the training.

For example: "I live in Tongi near the board bazaar (market place) where I can sell stuffed dolls and push puppets. My daughter can help me." (Female, intermediate age, 39)

More two said, respectively:

"Nobody likes to hire us. Who will give me a job? Therefore, I have come here to learn some work with which I can do something of my own". (Male, age, 25)

"I've heard of Disable's homes from one of my neighbors. I do have plans to join my brothers business after finishing training from here. He has a small souvenir shop, there I can supply handcraft goods".
Common response was they were planning of something to do in future with the skills they were hoping to learn from Disable's home. In other words, they were highly hopeful about their training in Disable's home. A possible explanation for the sudden rise in adrenalin may lie with their background. These people earlier did not receive any kind of nurturing from the societal point of view and as such even a small help created a profound effect on their mental set up. These finding's do match with findings of Herron and Sapienza, (1992); Gist, (1987) ; Gist and Mitchell, (1992) ; Bandura, (1982); Boyd and Vozikis, (1994); Krueger and Brazeal, (1994). That is people gain self-efficacy in supportive environment.

Again at the end of the training period, we revisited Disable's home and the same group was asked with second set of question (Set B) to find out whether there is any change in the level of self-efficacy that believes in their selves to set up their own business after their training. Surprisingly, a very disheartening picture came out. We asked about the training they received in Disable's home and whether they think it will be useful for their own business set-up? The trainees replied the training was good but they also informed us, it helped them to learn the work but they were worried about practicality of real life business set up as they didn't know many vital things about running a small business. Moreover, the main constraint is revolving around financial issues and social support.

The answer to the question whether they have any external support to set up their own business after leaving Disable's homes, was also not very satisfactory. Six people out of ten in the focus group who were very hopeful at the beginning seemed to be not so confident at the point of exit from the training. The lady who wanted to sell handcraft goods with the help of her daughter in the beginning told us:

"I have talked with my daughter to assist me in selling hand made goods in the market. My daughter wants to help but the problem is money to buy necessary materials for hand-craft goods. My husband is a porter in the market and earns very less, he may not be able to help me". (Female, intermediate age, 39)

Out of ten people three adults were absolutely homeless and they were staying in Disable's home since they were brought here from orphanage. So these three, neither they have any intention to leave the home nor they have any plans to set up their own business. But they were involved in the training program so that they can learn \& assist future trainees.

Through the conversation we also came to know that management of Disable's home pays 6000 taka (approx. $\$ 60)$, to each trainee when they finish their training as their seed capital. But while conversing with the focus group, the common voice was:

"We with such a meager amount of seed capital it is next to impossible to set our own business". (Male, intermediate age, 35yrs) 
As most of the participants' family background is very poor \& the saddest part is they are burdens for their family. One of the participants told us

"My own parents $\mathcal{E}$ other family members suggested for begging on the street $\mathcal{E}$ finance ourselves as it is too much for them to look after me. It is myself pride that brought me here to learn some skills so that I can earn a decent living. But I need other support as well, to have my own business". (Male, intermediate age 35)

When asked about their future plans again at the end of the training to check their confidence level after their training, mostly who were planning to have their own business in the beginning they now planning to look for handicraft job which they can do from home \& supply to different organizations. And in the worse case they kept begging for survival as their alternate choice. This findings is similar to perceptual control theory Powers's (1991). High self-efficacy is acting as a debilitate when their performance as entrepreneurs is ambiguous.

Phase two of this case study is from organization's perspective that how they are helping to boost self confidence among the disable trainees. The underlying concept for this part of the study comes from Arenius and Minniti (2005) study, that higher education can help people to be entrepreneurs. So if education providing institutions are themselves strong in terms of resources, only then they can do better job in training and educating others.

To study the strengths and weaknesses of Disable's home we took interview of the manager, one of the directors and an officer.

The manager, director \& the officer's responded in a similar way and more or less similar answers were received. We asked about the constraints Disable's home faces while training and supporting the disable members they have at present. This question was asked with the belief that efficiency of the institution is mostly related with the constraints they face. The manager informed us: "Disable's home is a non-profitable charity institution for special people, which runs on charity. Therefore, the biggest constraints include lack of resources that includes monetary and non monetary resources such as skilled trainers appropriate for disables, training materials etc."

On the other hand director informed us that though there are many wealthy people in the society but few are willing to donate for special people with special needs. Though Disable's home does work in association with other NGOs, but their day to day operations are largely dependent on donations of wealthy individuals.

When asked about support (question b, of phase two), the manager informed that basically the trainee selected for training are moderately disable who may not have a limb or can't hear properly. They don't train people who are visually impaired or mentally disable. This is due to the lack of proper teachers necessary for these kinds of disabilities \& lack of technology to train these people. Also the country lacks proper infrastructure for utilizing this kind of disable people.
Basically, trainees were given training on making handcraft goods but not on any other type of skills. Another interesting fact, the director, informed us that these people were trained on the job and the products they make are sold by the management. The money which is generated, portion of it is paid to the trainees and the rest go to the fund of the Disable's home. But this amount is very less. The officer informed us, the teachers who come in the home also works for free. Very little and not enough training is given on entrepreneurship. From the interview with the manager we also came to know that only few people stay in the premises but rest of the trainees commute from their own home during the training period.

In answering what could have been better (question c, phase II), both the officer \& director told us if they could get associated with any government agency probably they could get more monetary fund. Also, if they could hire proper skilled trainers that would have helped a lot. But at present this is a private organization and runs solely on donations so they are limited to the kind of support they can offer. Though they have land in their possession, nature of the organization would not permit them to undertake any profit making venture. The officer told us in a very helpless manner

"A well known handcraft shop in town, used to place order for their goods in Disable's home but now they have withdrawn that contract and has given to other big NGOs. They used to pay good money with which they could accommodate more people in the training program. But now at present we don't have any such big contracts".

\section{DISCUSSION}

\section{Phase one}

Wide-ranging programs of research with special focus on the role played by beliefs of personal efficacy in occupational choice and preparation have been instigated by Social cognitive theory of career choice (Betz \& Hackett, 1997; Lent et al 1994). Similarly, this study intended to make contributions regarding selfefficacy which arised from social cognitive theory by Bandura. Here we analyzed self-efficacy of disable people in becoming entrepreneur by doing a study on training program provided by Disable's home.

Overall summary of the results found in this case study showed that there were persuasive evidences that perceived desirability and intension towards entrepreneurship developed temporarily but varied among the disables before and after the training.

Our argument was based on the concept of 'self-efficacy' to explain whether people who were less fortunate in terms of their physical ability can gain confidence to have their independent business provided they get proper support. This argument was developed by taking the gist of the studies done by Herron and Sapienza, (1992) ; Gist, (1987) ; Gist and Mitchell, (1992) ; Bandura, (1982); Boyd and Vozikis, (1994); Krueger and Brazeal, 
(1994). These authors suggested that self-efficacy was not biologically obtained but could be acquired by experience, learning, and social persuasion, as discussed in the literature. The acquired skills, experiences, knowledge would in return strengthen one's selfefficacy. And negative factors, for example, lack of social persuasion, lack of family support, and absence of financial ability may weaken one's self- efficacy.

In Phase one of this study, we observed, when the trainees got support from Disable's home and were trained, they gained self-efficacy and so they were optimistic about their future career, as entrepreneurship. This supports findings of Bandura (1997), which says, supportive relationships can enhance the level of perceived selfefficacy in people by modeling effective coping attitudes and strategies to manage problem situations, by demonstrating the value of perseverance, and by providing positive incentives and resources for efficacious coping (Bandura, 1997). However, at the end of the training, when they were about to exit and institutional support was about to terminate, they were worrying about the external support. These included family, financial and social supports. And therefore the acquired self-efficacy didn't sustain for long. From this analysis, an interesting finding came out which supported perceptual control theory Powers's (1991) that is, high self-efficacy is a debilitator only when performance is ambiguous, thus allowing leeway to decrease the perceived goal. That is, the people who were trained had only knowledge gathered from training without having any other essential support to be entrepreneur. So, for them the entrepreneur field is very ambiguous, in addition, whether their performance will lead to success is uncertain. Thus, at the point of exit, high self-efficacy gained through training acted as a debilatator. This may be another reason why the people were not so positive during exit time as they were in the middle of the training.

\section{Phase two}

Institution can play a large role in developing self-efficacy among emerging disables in their self-sustaining career. Disable's home is doing a good job in taking initiative but they do have their own lacking. First, due to being a charity organization, they don't have enough human resources and capital resources. Second, they do provide each trainee taka 6000 (approx. \$60)at the point of exit as their seed capital, which is not enough to set up a business of their own. Third, after the trainees' exit they do not follow up and provide further support. If any trainee comes back on their own for further suggestion/ help then only they help. So, the effectiveness of their program goes unevaluated. As Arenius and Minniti (2005) said, higher education can help people to be entrepreneurs and so education providing institutions must be themselves strong in terms of resources in order to provide proper training \& education. In many cases Disable home fails to do it for their own weaknesses.

\section{LIMITATION OF THE STUDY}

We had to face some limitations, such as, not many institutions are there who support disable people in a developing country like Bangladesh. Finding a proper institution which will support our interest was a difficult phase. In addition, talking with the disables and getting their point of view was another hurdle we had to pass. Generally, the people we interviewed are among the highly neglected people of the society due to their disabilities. Therefore, when we interviewed them, some got carried away with the attention and some were over conscious about what they were saying. So information gathered may not be bias free. Moreover, Disable's home does not maintain comprehensive data base about the trainees once they exit this program. As such it was not possible for us to ascertain the effectiveness of such program for the disables.

\section{CONCLUSION}

As most of the nations' economy is still developing in South East Asia like Bangladesh, India, Pakistan and others, there are not ample supports for disable people. Generally, the disables are considered to be a burden for the family as well as the society in these regions. However, through institutional support and provided they get family ,social, financial supports, these minorities can be transformed into valuable assets through their career selfefficacy development and can contribute to their national economies. Through our study findings we realized that it is not impossible to train people with physical disabilities but due to lack of various supports, their self-efficacy towards entrepreneurship may not be sustained in the long run. As a result many potential entrepreneurs withers away. If big corporations and wealthy individuals come forward in educating, training these individuals there self-efficacy can be much enhanced towards their career. Unfortunately, most of the studies that were conducted were based on general able work force. But these minorities, like disable people, do add values to the economy remain largely ignored by us researchers. Specially, a developing country like Bangladesh where there is lack of institutions which provide career support \& guidance for the disables there is a growing need for conducting research relative to effectively utilize these potential manpower. With this view, the study made an attempt to explain importance of self-efficacy in career choice of these minorities. Though this study is done on a case basis but can be a platform to do an in depth empirical study taking wider factors that affect selfefficacy and its sustainability among minorities in their career choice. 


\section{REFERENCES}

Arenius, P. \& Minniti, M. (2005). Perceptual Variables and Nascent Entrepreneurship. Small Business Economics 24(3): 233-47.

Arenius, P. \& De Clercq, D. (2005). A Network-based Approach to Opportunity Recognition. Small Business Economics 24(3), 249-65.

Atkinson,N.L. (2009). Benefits, Barriers, and Cues to Action of Yoga Practice: A Focus Group Approach. Am J Health Behav. 33(1):3-14

Bandura, A. (1978). Reflections on self-efficacy. Advances in Behaviour Research and Therapy,(1), 237-269

Bandura, A., Barbaranelli, C., Caprara, G., \& Pastorelli, C. (2001) .Self-efficacy beliefs as shapers of children's aspirations and career trajectories. Child Development, 72(1), 187-206.

Bandura,A. (1997). Self-efficacy : The exercise of Control. New York: Freeman.

Bandura. A. (1977).Social learning theory. Englewood Cliffs, NJ: Prentice Hall.

Bandura.A. (1982).Self-efficacy mechanism in human agency. American Psychologist , 7(2), 122-147.

Barbotte E, Guillemin F, Chau, N. (2001). Prevalence of impairments, disabilities, handicaps and quality of life in the general population: a review of recent literature. Bull World Health Organ 79, 1047-55.

Betz, N. E., \& Hackett, G. (1997). Applications of self-efficacy theory to the career assessment of women. Journal of Career Assessment, 5, 383-402.

Boyd, N., \& Vozikis,G. (1994).The Influence of Self-Efficacy on the Development of Entrepreneurial Intentions and Actions, Entrepreneurship Theory and Practice 18, 28-36.

Brown RI (1988). Quality of life and rehabilitation: an introduction. In: Brown RI, editor. Quality of life for handicapped people. New York: Croom Helm,2-5.

Burgelman RA. 1983. A model of the interaction of strategic behavior, corporate context and the concept of strategy. Academy of Management Review 8(1): 61-70.

Burrows D \& Kendall S (1997) Focus groups: What are they and how can they be used in nursing and health care research? Social Sciences in Health 3, 244-253.

Burt, R. S. (1992).The Social Structure of Competition, in N. Nohria and R. G. Eccles (eds) Networks and Organizations: Structure, Form and Action (pp. 57-91). Boston, MA: Harvard Business School Press.

Chen, C., Greene, P., \& Crick, A. (1998). Does entrepreneurial self-efficacy distinguish entrepreneurs from managers? Journal of Business Venturing, 13, 295-316.

Creswell, J.W (1997). Qualitative Inquiry and Research Design: Choosing Among Five

G.M. Monawar Hosain, David Atkinson, and Peter Underwood (2002) . Impact of disability on quality of life of rural disabled People in Bangladesh. Journal of Health, Population and Nutrition, Vol. 20, No. 4 (December 2002), pp. 297-305

Gibbert M., Ruigrok W., Wicki B., (1998).What passes as a rigorous case study? Strategic Management Journal Strat. Mgmt. J. 29: 1465-1474

Gist, M. E., \& Mitchell. T. R. (1992). Self-efficacy: A theoretical analysis of its determinants and malleability. Academy of Management Review,17(2).

Gist. M. E. (1987). Self-efficacy: Implications for organizational behaviour and human resource management. Academy of Management Review, 12(3), 472-485.
Herron. L., \& Sapienza, H. J. (1992). The entrepreneur and the initiation of new venture launch activities Entrepreneurship Theory and Practice, 17(1), 49-55.

Hollenbeck G, Hall DT (2004). Self-confidence and leader performance. Organ. Dyn. 33(3),254-269.

Imrie R. (1997). Rethinking the relationships between disability, rehabilitation, and society. Disabil Rehabilation19, 263-71.

Kickul, J. \& D'Intino, R. (2004, January). Measure for measure: modeling entrepreneurial self-efficacy onto instrumental tasks within the new venture creation process. Presented at the United States Association for Small Business and Entrepreneurship Conference, Dallas, TX.

Kidd, M. P. , Sloane, P. J. \& Ferko, I. (2000). Disability and the labour market: An analysis of British male. Journal of Health Economics 19, 961-981.

Krueger, N.F., Jr. \& Brazeal, D.V. (1994). Entrepreneurial potential and potential entrepreneurs.Entrepreneurship Theory \& Practice, 18(3), 91-104.

Lent, R. W. \& Hackett, G. (1987). Career self-effieacy: Empirical status and future directions Journal of Vocational Behaviour, 30, 347-382.

Lent, R. W., Brown, S. D., \& Hackett, G. (1994). Toward a unifying social cognitive theory of career and academic interest, choice, and performance. Journal of Vocational Behavior, 45, 79-122.

Mont,D. (2004).Disability employment policy. Retrieved From : http://digitalcommons.ilr.cornell.edu/cgi/viewcontent.cg i? article $=1433 \&$ context $=$ gladnetcollect

Nevill, D. \& Schleckler, D. (1988).The relation of self-efficacy to willingness to engage in traditional/non-traditional career activities.Psychology of Women Quarterly, 12, 91-98.

Penrose ET. 1960. The growth of the firm. A case study: the Hercules powder company. Business History Review 34(1): 1-23.

Pettigrew A. 1973. The Politics of Organizational Decision Making. Tavistock: London, UK.

Powers, W. T. (1991). Comment on Bandura's "human agency." American Psychologist, 46, 151-153.

Putnam, R. (1993) Making Democracy Work. Princeton, NJ: Princeton University Press.

Scherer,R.,Adams.J., Carley, S., \& Wiebe.F. (1989). Role model performance effects on development of entrepreneurial career preference. Entrepreneurship Theory and Practice, 13(3), 53-81.

Thomas L, MacMillan J, McColl E, Hale C \& Bond S (1995) Comparison of focus group and individual interview methodology in examining patient satisfaction with nursing care. Social Sciences in Health 1, 206-219.

Traditions.Thousand Oaks, CA: Sage Publications1997.

Wood,.R.,\& Bandura. A. (1989). Social cognitive theory of organizational management. Academy of Managemenl Review, 14(3), 361-384.

World Health Organization. International classification of impairments, disabilities, and handicap: a manual of classification relating to the consequences of disease. Geneva: World Health Organization, 1980:3-13. 2.

World Health Organization. Study protocol for the World Health Organization project to develop a Quality of Life assessment instrument (WHOQOL). Qual Life Res 1993;2:153-9.

$$
-0 \text { - }
$$

